\title{
FLOATING SLOPES METHOD APPLICATION ON THE COAL DEPOSIT KONGORA
}

\author{
Ivo Galić, Dragan Krasić
}

Original scientific paper Developing three-dimensional geological and economical models of deposits in combination with deposits economical values calculations, represents a fundament for application of contemporary methods in the mining engineering. It is proved that contemporary methods, such as Lerchs-Grossman's method, Method of floating cone and Dynamic programming, are excellent models for generating the algorithm for contour optimization of an open pit mine. The exploration of the optimal pit contour can be a relatively simple and fast process if specialized mining software is utilized. The simplicity, quickness and reliable results offer a wide range of contemporary methods applications built in many mining computing programs. Based on available contemporary methods and their elementary criteria (optimality, stability and slope stability), authors suggest an innovative method of open pit contour optimization, named "Floating Slopes Method (FSM) ". This paper presents synthesis of results of FSM application on the coal deposit "Kongora".

Keywords: coal deposit Kongora; contour optimization; Floating Slopes Method

Primjena metode pomičnih kosina na ležištu ugljena "Kongora"

Izvorni znanstveni članak

Izrada geološkog i ekonomskog modela ležišta u trodimenzionalnom okruženju, uz popratne baze podataka i proračune ekonomskih vrijednosti ležišta predstavlja temelj za primjenu suvremenih metoda u rudarstvu. Suvremene metode, kao što su: Lerchs-Grossmann-ova (LG) metoda, metoda pomičnog stošca i metoda dinamičkog programiranja, poslužile su kao izvrstan predložak za izradu programa optimalizacije kontura površinskih kopova. Računalna tehnika omogućila je iznalaženje optimalne konture kopa preko algoritama ugrađenih u profesionalne i namjenske programe. Brzina i jednostavnost rada te dobivanje pouzdanih izlaznih rezultata omogućili su široku primjenu suvremenih metoda, ugrađenih u puno računalnih programa.Temeljem osnovnih kriterija suvremenih metoda (optimalnost, stabilnost i kompatibilnost kosina) autori su predložili metodu optimalizacije kontura površinskog kopa koja je nazvana metoda pomičnih kosina (MPK).Ovaj rad je objedinio rezultate primjene MPK na ležištu ugljena "Kongora".

Ključne riječi: ležište ugljena Kongora;metoda pomičnih kosina; optimalizacija kontura

\section{Introduction}

The coal deposit "Kongora" is a polygon for scientific research focused on exploitation of significant energy potential of the area. Therefore, the researchers used the opportunity to explore the optimal contour that can be derived from the geological and economical models. Contemporary designing methods, such as: LerchsGrossmann's method [1, 16, 18], Floating cone method $[2,3]$ and the dynamic programming method [12, 21], are applicable only within the computer software [15]. Majority of these methods are primarily based on the ore bodies characteristics.

Contemporary mining methods consider primary ore - metal deposits. Ore deposits usually have highly scattered forms, variable size, and often highly discontinued distribution of ores within the deposit. These characteristics are conditioning needs for highly complex researches in the process of open pit mine development $[4,6]$. The beginning of any contemporary pit mine design is construction of 3D geological model, and follows the segmentation of the deposit in blocks or grid assigning economical and technical values to the blocks $[19,20]$. Final goal is to optimize the open pit limits with the maximal angle of the final pit slope, and minimal production costs. The balance between these factors generates maximum net profit. Complex geological settings of deposits and instability of the ore market price, indicate and often dictate the choice of the optimal pit design method [5, 14].

Software solutions in design of the open pits are mainly focused on the large scale open pit metal mines. The accuracy of obtained results for stratified - bedded types of deposits (non-metals and coal) is questionable. The concerns are highlighted in the case of inclined multi-seams coal deposits and where the seam footwall dictates the position of the final open pit slope. Furthermore, the variation of the ore grade in metal deposits is more frequent than in non-metal - coal deposits. This approach encouraged scientists to develop an alternative optimization method. Newly developed method, called "Floating Slopes Method (FSM)", considers identified disadvantages of standard optimization methods [7, 9].

The coal deposit "Kongora" in Bosnia and Herzegovina was used as an illustrative example of results obtained by exploring the FSM method $[8,9]$.

Algorithm (FSM) was used to:

- Develop 3D geological model

- Develop 3D block model of deposits

- Design the input database for the economic model

- Determine cost parameters and create economic model of reserves

- Determine the optimal and specific contour of a surface mine and its limitations

- Develop optimal 3D graphic view of the contour and / or any other contour of the surface mine.

Geological settings presented by 3D geological model dictate the shape of the pit mine contours. Hypothetically, in the geological model, one optimal contour can exist only, and all other contours are less favourable or unfavourable. However, the optimal contour may not always be financially viable. Requirements to consider optimal contour in calculations sometimes differ from the economic peak. Therefore, the method of moving slope uses the contour in which crucial requirement is the energy value that will be obtained from the thermal power plant in a specific time frame. 
If the applied contour is in a function of the exploitation of another object (for example "Kongora" to the thermal power plants), then applied contour will be a variable rather than a fixed value. Changing the market positions, increasing or decreasing of prices equivalents (energy and / or similar equivalent) may establish a new production goal, and this would replace dedicated contour to another position of the open pit mine.

\section{Features of the Floating Slopes Method 2.1 Assumptions of the Floating Slopes Method (FSM)}

Floating Slopes Method (FSM) is the method based on a new calculation approach, and is characterized by several initial assumptions. Assumptions are related to the theoretical aspects of 3D pit designing, and the principle of gaining maximum net profit from the deposit exploitation. They are applied to the mathematical model with the aim to achieve optimal open pit limits, described in the section $3[7,8,9]$.

These assumptions consider the following elements and successive steps in mine optimization process:

a. The 3D geological model of a deposit is developed and subdivided into blocks. Blocks could be of equal, or various, size and shape, depending on the size and geometry of mineral deposits.

b. Segmentation of a deposit model into the blocks has been made by crosscutting of a deposit model with longitudinal and transversal sections, in order to properly simulate the shape of mineral deposit.

c. Horizontal segmentation of a deposit model was made with parallel horizontal sections of equal distances.

d. Dimensions of the blocks are determined with the functional relation of block height-width-length that presents tangent line of the final pit slope angle.

e. Any block inside the geological model of a deposit has been subordinated to the belonging slope. A block can present the slope only if it is diagonally underneath and other blocks do not exist above (the first block from the surface of terrain).

f. All blocks in the geological model are assigned the following characteristics: quantity of ore-coal and hanging wall strata, average quality of ore-seam, equivalent of the ore value, the cost of exploitations and exploitation expenses for the belonging blocks.

g. The following input parameters and data had to be recorded in the database (for every block): market price of the mineral equivalent values $\left(C_{t}\right)$, basic cost of block exploitation $\left(C_{i, j, k}\right)$, quantity of mineral-coal in the block $\left(G_{i, j, k}\right)$, average quality of ore-coal in the block i.e. equivalent value of ore-coal in the block $\left(E_{i, j, k}\right)$, quantity of waste in the block $\left(O_{i, j, k}\right)$, and exploitation expenses for the block $\left(T_{i, j, k}\right)$.

h. Based on input values, the following parameters are calculated: unit price of block exploitation in the pit slope $\left(C_{\text {unit }}\right)$, average price of mineral exploitation $\left(C_{a v}\right)$, total quantity of mineral-coal $\left(G_{t}\right)$, total equivalent value of mineral-coal in the pit $\left(E_{t}\right)$, total quantity of overburden $\left(O_{t}\right)$, and total costs of exploitation $\left(T_{t}\right)$. i. Calculations of input values, and all parameters related to the open pit optimization, were imported to the economic model.

j. Unit price of block exploitation $\left(C_{u n i t}\right)$ is always related to the sum of values of all blocks, from considered block to the lowest block in the open pit slope.

k. Procedure of estimating favourable slopes starts from the shallowest part of the deposit.

1. Procedure of estimating favourable slopes can be applied through the order: from the left to the right, from the right to the left and simultaneously from the left and from the right.

$m$. There are three possibilities of final open pit limit:

n. Optimal open pit limit $\left(P_{O}\right)$. This is assessment of the most appropriate (maximum) net present value of the open pit.

o. Applied open pit limit $\left(P_{A}\right)$. This is assessment of the open pit value including the obligatory economic factors (for example for coal: coal power plant capacity of thermo blocks - the annual power production - the number of years in operation, etc.).

p. Contoured pit limit $\left(P_{T}\right)$. This assessment of the pit value is based on the long-term analysis and forecasting of price trends in mineral market prices, including obligatory time factor. In this open pit limit has neither profit nor loss.

\subsection{Numerical expressions for open pit limit determination}

Open pit limit is determined by a set of numerical expressions, developed by relating essential input data and 3D block extraction order [7, 8, 9].

\subsection{Input data for open pit limit determination}

The basic expression for net value of an open pit is the following:

$$
P=E_{t} \cdot\left(C_{t}-C_{a v}\right)
$$

$P$ - net profit, monetary unit (mon. unit)

$E_{t}$ - the total quantity of mineral-coal, expressed in the equivalent units (eq), which was excavated within the pit limits - for coal $(\mathrm{J})$, for ore $\left(\mathrm{m}^{3}\right)$

The total equivalent of mineral-coal value in the open pit is calculated by the following formula:

$$
E_{t}=\sum E_{i, j, k}
$$

$E_{i, j, k}$ - the equivalent block value $b_{i, j, k}(\mathrm{eq})$

$i, j, k$ - number of rows $(i=1, \ldots, n)$, columns $(j=1, \ldots, m)$ and block columns $(k=1, \ldots, r)$

$C_{t}$ - world market price of mineral raw material, (mon. unit/eq)

$C_{a v}$ - average, i.e. production price of mineral-coal, (mon. unit/eq)

The production price of mineral-coal is calculated as follows: 
$C_{a v}=\frac{T_{t}}{E_{t}}$

$T_{t}$ - total production cost of mineral-coal, (mon. unit)

Total cost of exploitation of mineral-coal is:

$T_{t}=\sum T_{i, j, k}$

$T_{i, j, k}$ - costs of exploitation of the block $b_{i, j, k}$, (mon. unit)

$T_{i, j, k}=T_{i, j, k}^{E}+T_{i, j, k}^{O}$

$T^{E}{ }_{i, j, k}$ - production costs of mineral-coal equivalent in the block (mon. unit)

$T_{i, j, k}^{O}$ - overburden removal costs in the block $b_{i, j, k}$, (mon. unit)

\subsection{Numerical expressions for optimal pit limit determination}

FSM considers estimation of the optimal open pit limit, by beginning of calculations from left to right side and inversely, or combined, that means simultaneously from the left and from the right side. The direction of calculation depends on the mineral deposit geometry, and on the starting point of block model. Depending upon the incline of ore deposit or coal seam and direct relationship with final open pit slope, the following expressions for the pit optimization are given.

Value of contours of open pit is calculated as follows:

$$
P_{t}=P_{i, j, k}^{L-R}+P_{i, j, k}^{R-L}-P_{i, j, k}^{L-R} \cap P_{i, j, k}^{R-L}
$$

$P_{t}$ - the total value of open pit (up to the block $b_{i, j, k}$ ), which includes optimization process from the left to the right side and vice versa, and eliminates values which occur twice during the calculation progress

$P^{L-R}{ }_{i, j, k}$ - value of open pit obtained by the optimization from the left to the right side, up to the block $\left(b_{i, j, k}\right)$ $P^{R-L}{ }_{i, j, k}$ - value of open pit obtained by the optimization from the right to the left, up to the block $\left(b_{i, j, k}\right)$

$P^{L-R}{ }_{i, j, k} \cap P_{i, j, k}^{R-L}$ - overlapping of blocks which appears in both procedures

Optimization of open pit limit from the left to the right side can be calculated by the expression:

$$
P_{i, j, k}^{L-R}=S_{i, j, k}^{L-R}+\max \left\{\begin{array}{l}
k_{i+1, j, k} \\
k_{i+1, j+1, k} \\
k_{i, j+1 . k} \\
k_{i-1, j+2, k} \\
k_{i-2, j+3, k} \\
\vdots \\
k_{0, j+n, k}
\end{array}\right\}
$$

$P^{L-R}{ }_{i, j, k}$ - the value of open pit, obtained by optimization from the left to the right side, up to the block $\left(b_{i, j, k}\right)$, which, beside the cone $\left(S_{i, j, k}\right)$, includes most favourable slope from the right side (most favourable compatible slope from the right of the cone is one which generates the maximum value of open pit, under the condition that the slope is within the exploitation sector), $S_{i, j, k}^{L-R}$ - the value of open pit (from the left to the right side) up to the slope in which block $\left(b_{i, j, k}\right)$ presents the lowest level.

Block value is determined with numerical calculation, and is treated as the lowest one and the most favorable block of mineral - coal. The unit price, costs of production, and equivalent value of mineral - coal was assigned to the block. Every block subordinates the slope, because only when there are all blocks above treated one excavated, the treated block can be added to the calculation. As distinction from that, extraction of blocks above the block $\left(b_{i, j, k}\right)$ would not come in consideration, unless the profitability of block $\left(b_{i, j, k}\right)$ is justified.

For the example, the block $\left(b_{i, j, k}\right)$ presents the mineral - coal, and blocks above present the overburden in the belonging slope. Exploitation of block $\left(b_{i, j, k}\right)$ would not be possible (by surface mining) without removal of overburden blocks, while the removal of overburden blocks is meaningless without extraction of block $\left(b_{i, j, k}\right)$ (Fig. 1). This situation demands that stability of final pit slopes is maintained. Therefore, to every block within the slope, unit prices are assigned (regardless if the block contains ore - coal or overburden), in relation to the gained profit and related expenses of exploitation.

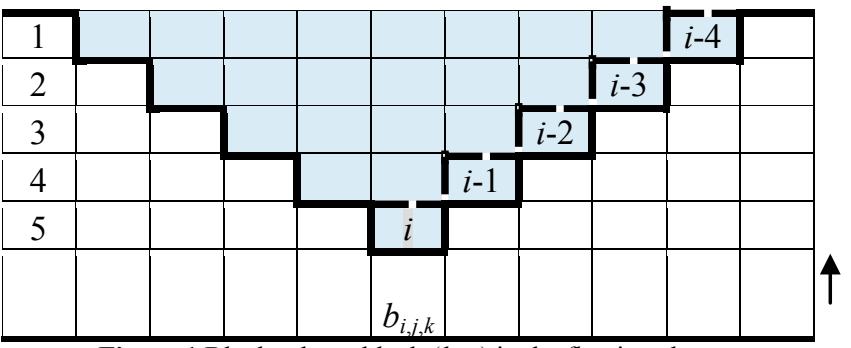

Figure 1 Blocks above block $\left(b_{i, j, k}\right)$ in the floating slope

Based on the general formula (1), the value of optimal open pit has been determined, where the block $\left(b_{i, j, k}\right)$ is the lowest one in the considered pit slope that would be excavated last:

$S_{i, j, k}^{L-R}=\sum E_{i, j, k}^{L-R} \cdot\left(C_{t}-C_{a v}\right)$

Based on the expression (3), the average price $\left(C_{a v}\right)$ can be calculated by dividing the sum of production cost and equivalent values of mineral - coal, therefore the formula (7) can be transformed into the following:

$S_{i, j, k}^{L-R}=\sum E_{i, j, k}^{L-R} \cdot\left(C_{t}-\frac{\sum T_{i, j, k}^{L-R}}{\sum E_{i, j, k}^{L-R}}\right)$

After arranging the equation members, the final formula used for computerized model was derived: 


$$
S_{i, j, k}^{L-R}=C_{t} \cdot \sum E_{i, j, k}^{L-R}-\sum T_{i, j, k}^{L-R}
$$

$\sum E^{L-R}{ }_{i, j, k}$ - sum of equivalent value of mineral - coal in the pit limit, where the block $\left(b_{i, j, k}\right)$ presents the lowest level of the last concerned slope

$\sum T_{i, j, k}^{L-R}$ - sum of costs of exploitation of mineral - coal in the pit limit, where the block $\left(b_{i, j, k}\right)$ presents the lowest level of the last concerned slope

$k_{i+1, j, k}$ - value of slope which begins on the block $\left(b_{i+1, j, k}\right)$. This is excavation for one height of block, in an equal width of block

$k_{i+1, j+1, k}$ - value of slope which begins on the block $\left(b_{i+1, j+1, k}\right)$. This is excavation for one height and double width of block

$k_{i, j+1, k}$ - value of slope which starts on the block $\left(b_{i, j+1, k}\right)$. This is expansion of the pit for one width of the block without further excavation in depth

$k_{i-1, j+2, k}$ - value of slope which starts on the block $\left(b_{i-}\right.$ $1, j+2, k)$. This is deepening of the pit for one height of the block and expansion for two widths of block

$k_{i-2, j+3, k}$ - value of slope which starts on the block $\left(b_{i-}\right.$ $2, j+3, k$ ) (reduction of deepening of the pit for the two heights of the block and expansion for three widths of blocks)

$k_{0, j+r, k}$ - value of slope which starts on the block $\left(b_{0, j+r, k}\right)$. This is the block of air.

Mineral - coal and exploitation costs were calculated along the slopes, by adding the equivalent values in the universal numerical expression for all three factors:

$$
\begin{aligned}
E_{i, j, k}^{k} \text { or } T_{i, j, k}^{k} \text { or } C_{i, j, k}^{k}= & b_{i, j, k}+b_{i-1, j+1, k}+b_{i-2, j+2, k}+ \\
& +\ldots+b_{i-r+1, j+r-1, k}+b_{i-r, j+r, k}
\end{aligned}
$$

$E_{i, j, k}^{k}$ - sum of equivalent value of mineral - coal in the slope, where the block $\left(b_{i, j, k}\right)$ presents the lowest level of concerned slope,

$T^{k}{ }_{i, j, k}$ - sum of costs of exploitation of mineral - coal in the slope, where the block $\left(b_{i, j, k}\right)$ presents the lowest level of concerned slope,

$C_{i, j, k}^{k}$ - sum of the unit price of mineral - coal in the slope, where the block $\left(b_{i, j, k}\right)$ presents the lowest level of concerned slope.

$b_{i, j, k}$ - the belonging value (depending on type of data being added: cost, equivalent or the price) in the lowest block of slope $\left(k_{n}\right)$,

$b_{i-1, j+1, k}$ - the second block of slope $\left(k_{n}\right)$, positioned diagonally above the block $\left(b_{i, j, k}\right)$,

$b_{i-2, j+2, k}$ - the third block of slope $\left(k_{n}\right)$, positioned diagonally above the block $\left(b_{i-1, j+1, k}\right)$,

$b_{i-r+1, j+r-1, k}$ - penultimate block of slope $\left(k_{n}\right)$. This is the second block from the terrain surface.

$b_{i-r, j+r, k}$ - last, i.e. the highest block of slope $\left(k_{n}\right)$. This is the first block from the terrain surface.

$r$ - Total number of blocks in the slope $\left(k_{n}\right)$ above the block $\left(b_{i, j, k}\right), r=i-1$.

Sum of the unit prices in one slope present the average cost of exploitation of concerned slope, and this value is used explicitly for the acceptance, or the rejection, of specific slope. Average value of the whole pit limit is calculated by the formula (1), i.e. by the relation of total exploitation costs and total equivalent of mineral - coal.

Finally, the value of any slope in the pit limit is calculated by the formula:

$k_{i, j, k}=C_{t} \cdot \sum E_{i, j, k}^{k}-\sum T_{i, j, k}^{k}$

$k_{i, j, k}$ - value of slope which begins on the block $\left(b_{i, j, k}\right)$.

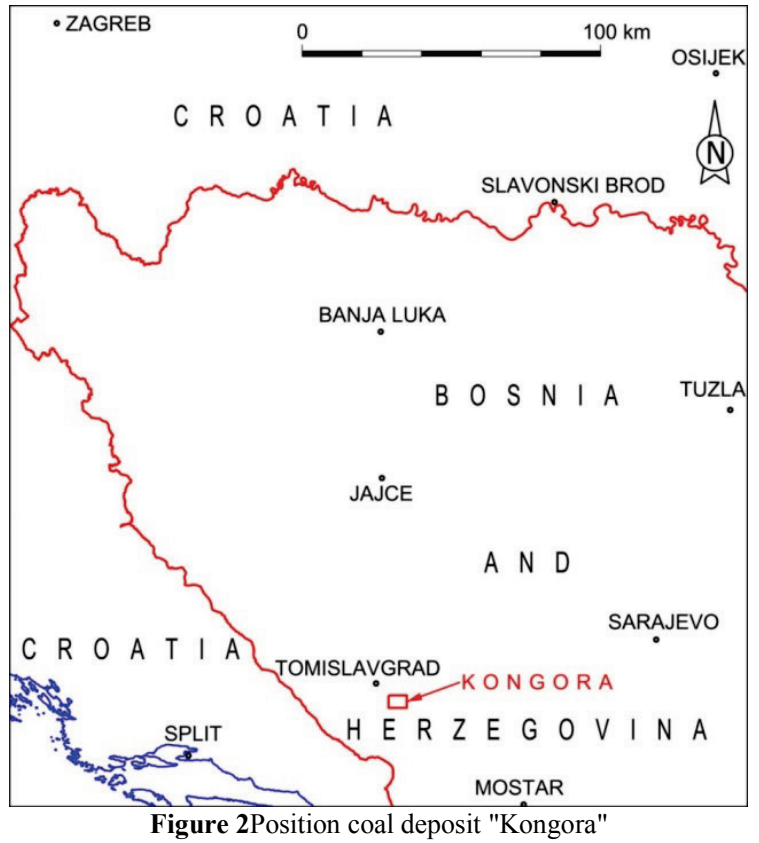

\subsection{The procedures of Floating Slopes Method optimization}

The procedure of pit limit optimization, using FSM, comprises a number of inter-related subsequent steps. Procedure of FSM consisted in five steps [7, 8, 9]:

Step A. Development of geological database

Step B. Generating 2D and / or 3D geological model of deposit

Step C. Development of mining database

Step D. Calculating of economic factors and developing database of economic data

Step E. Open pit limit optimization.

\subsection{Location and description of reservoir}

The deposit of lignite "Congora" is approximately 8 $\mathrm{km}$ southeast of the municipal centre Tomislavgrad in Bosnia and Herzegovina, (Fig. 2).

\section{Input data on coal deposit "Kongora" 3.1 Research work}

Intensive exploration of coal in the wider area of Duvanjsko polje begins in 1956 and finishes in 2008. 76 exploration drill holes with a total length of all wells of about 11520 m were drilled in coal deposit "Kongora". Results indicate that the "Kongora" is brachysyncline 
with E-W strike. Length of the structure is approximately $4 \mathrm{~km}$ and width of $2 \mathrm{~km}$ (Fig. 3).

In the area, four coal layers are developed and they are named on the basis of the position of the layer or according to the determined reserves (Fig. 4, Tab. 1), including:
- foot wall layer

- main layer

- interlayer and

- $\quad$ hanging wall layer.



Figure 3 Geological map of "Kongora" [17]

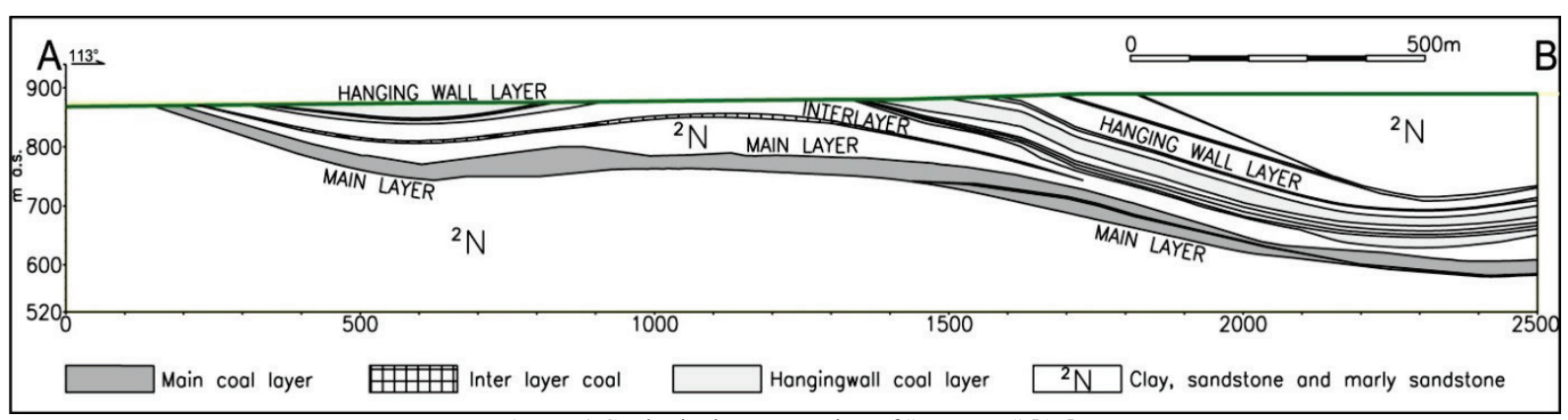

Figure 4 Geological cross-section of "Kongora" [17] 
Table 1 Determined reserves of coal in the deposit "Kongora" [11] Reserves of coal, $t$

\begin{tabular}{|c|c|}
\hline \multicolumn{2}{|c|}{ Reserves of coal, $\mathrm{t}$} \\
\hline Geological reserves & Balance reserves \\
\hline 225378000 & 169071000 \\
\hline
\end{tabular}

The calorific value is the most important feature of a fuel. In the sense of energetic value, quality of coal mainly refers to the calorific value or the amount of heat that is released during combustion. This is then the main feature in the evaluation and classification of coal (Tab. 2).

Table 2 Thermal value of coal, according to [10]

\begin{tabular}{|l|c|c|c|c|}
\hline \multirow{2}{*}{ Features of coal } & \multicolumn{4}{|c|}{ Coal layer } \\
\cline { 2 - 5 } & Hanging wall layer & Interlayer & Main layer & Footwall layer \\
\hline Selected average value, $\mathrm{kj} / \mathrm{kg}$ & 7325 & 6450 & 7700 & 10226 \\
\hline Average thickness, $\mathrm{m}$ & 24,22 & 2,2 & 28,6 & 0,8 \\
\hline
\end{tabular}

\section{Optimal contours of the "Kongora" open pit by applying the FMS algorithm}

Optimization of the "Kongora" open pit contour was accomplished by the FMS algorithm and is based on previous research results $[13,17]$.

\subsection{Geological model of the deposit}

The research results - the thickness of coal and intermediate layers were obtained from numerous boreholes and were entered into the input database in ASCII code. 39 surfaces for the basement and overburden of each coal and intermediate coal layer were made by Kriging interpolation method, and used as a basis for constructing of geological model of deposit.
Unifying all the surfaces of coal layers, intermediate layers and the surface of the ground, the 3D geological model of the deposit is concerned and shown on Fig. 5 and Tab. 3 [7].



Figure 5 Geological 3D model of the coal deposit "Kongora" [7]

\begin{tabular}{|c|c|c|c|c|c|c|c|c|c|c|c|c|c|c|}
\hline \multirow{2}{*}{$\begin{array}{l}\text { Number } \\
\text { block }\end{array}$} & \multicolumn{3}{|c|}{ Position block } & \multicolumn{3}{|c|}{ Overburden } & \multirow{3}{*}{\begin{tabular}{c|} 
Volume \\
$\mathrm{m}^{3} \mathrm{~s} . \mathrm{m}$
\end{tabular}} & \multirow{3}{*}{$\begin{array}{c}\text { Mass } \\
\mathrm{t}\end{array}$} & \multirow{3}{*}{$\begin{array}{c}\text { Spec. Energy } \\
\mathrm{kJ} / \mathrm{kg}\end{array}$} & \multirow{3}{*}{\begin{tabular}{|c|} 
Coal-energy \\
Energy \\
GJ
\end{tabular}} & & & \multirow{3}{*}{\begin{tabular}{|l|} 
Cost exploit. \\
monetary unit
\end{tabular}} & \multirow{3}{*}{$\begin{array}{c}\text { Total } \\
\text { cost } \\
\text { m. unit } \\
\end{array}$} \\
\hline & & & & Volume & Elem. Price & Cost exploit. & & & & & \multicolumn{2}{|c|}{ Elem. Price } & & \\
\hline & $i$ & j & k & $\mathrm{m}^{3} \mathrm{~s} . \mathrm{m}$ & m. unit $/ \mathrm{m}^{3}$ & monetary unit & & & & & m. unit/t & m. unit/GJ & & \\
\hline & & & & (1). & $(2)=5,047265$ & $(3)=(1) \times(2)$ & (4) & $(5)=(4) \times 1,42$ & (6) & $(7)=(5) \times(6) \times 10^{-3}$ & $(8)=3,554412$ & $(9)=(10) /(7)$ & $(10)=(5) \times(8)$ & $(11)=(3)+(10)$ \\
\hline 2384 & 7 & 14 & 10 & & & & & & & & & & & \\
\hline 2385 & 7 & 15 & 10 & 0 & 5,047 & 0 & 0 & 0 & 0 & 0 & 3,554 & 0,436 & 0 & 0 \\
\hline 2386 & 7 & 16 & 10 & 0 & 5,047 & 0 & 0 & 0 & 0 & 0 & 3,554 & 0,447 & 0 & 0 \\
\hline 2387 & 7 & 17 & 10 & 26.200 & 5,047 & 132.231 & 0 & 0 & 0 & 0 & 3,554 & 0,456 & 0 & 132.231 \\
\hline 2388 & 7 & 18 & 10 & 400.000 & 5,047 & 2.018 .800 & 0 & 0 & 0 & 0 & 3,554 & 0,471 & 0 & 2.018 .800 \\
\hline 2389 & 7 & 19 & 10 & 400.000 & 5,047 & 2.018 .800 & 0 & 0 & 0 & 0 & 3,554 & 0,486 & 0 & 2.018 .800 \\
\hline 2390 & 7 & 20 & 10 & 400.000 & 5,047 & 2.018 .800 & 0 & 0 & 0 & 0 & 3,554 & 0,480 & 0 & 2.018 .800 \\
\hline 2391 & 7 & 21 & 10 & 400.000 & 5,047 & 2.018 .800 & 0 & 0 & 0 & 0 & 3,554 & 0,477 & 0 & 2.018 .800 \\
\hline 2392 & 7 & 22 & 10 & 400.000 & 5,047 & 2.018 .800 & 0 & 0 & 0 & 0 & 3,554 & 0,473 & 0 & 2.018 .800 \\
\hline 2393 & 7 & 23 & 10 & 400.000 & 5,047 & 2.018 .800 & 0 & 0 & 0 & 0 & 3,554 & 0,468 & 0 & 2.018 .800 \\
\hline 2394 & 7 & 24 & 10 & 400.000 & 5,047 & 2.018 .800 & 0 & 0 & 0 & 0 & 3,554 & 0,468 & 0 & 2.018 .800 \\
\hline 2395 & 7 & 25 & 10 & 400.000 & 5,047 & 2.018 .800 & 0 & 0 & 0 & 0 & 3,554 & 0,468 & 0 & 2.018 .800 \\
\hline 2396 & 7 & 26 & 10 & 400.000 & 5,047 & 2.018 .800 & 0 & 0 & 0 & 0 & 0 & 0 & 0 & 2.018 .800 \\
\hline 2397 & 7 & 27 & 10 & & & & & & & & & & & \\
\hline
\end{tabular}

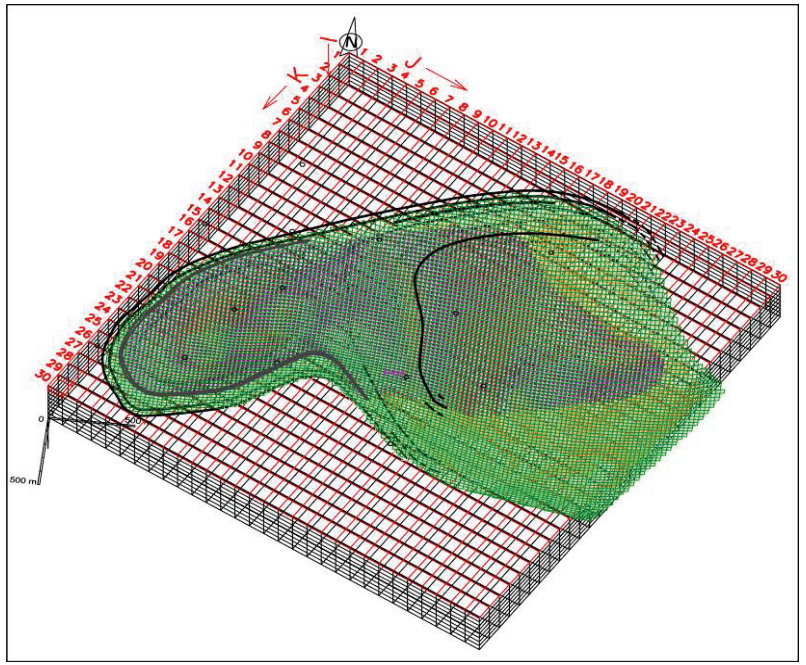

Figure 6 Block model of the coal deposit "Kongora" [7]

\subsection{Block model of the deposit}

Geological model of the deposit served as a base to build the block model of the deposits. For the purpose of managing geological data base, the block model of the deposits was developed with block dimensions of $100 \times$ $100 \times 40 \mathrm{~m}$ and the site arrangement of 30 columns $(k)$, 30 props $(j)$ and 8 files $(i)$. Thus, every block in the model got unique coordinates $i, j, k$ (Fig. 6).

\subsection{Economical model of the deposit}

Geological model and the block model of the open pit deposit were the base for designing an economical model of the deposit. The base for economic model was discretization of geological model on the equal size blocks. Economic model assigns exploitation cost values 
and an equivalent value of mineral raw material (expressed in the energy unit, GJ) to each block in the model (Tab. 4).

Table 4 Schematic illustration of the economic model (part of the table 10) [7]

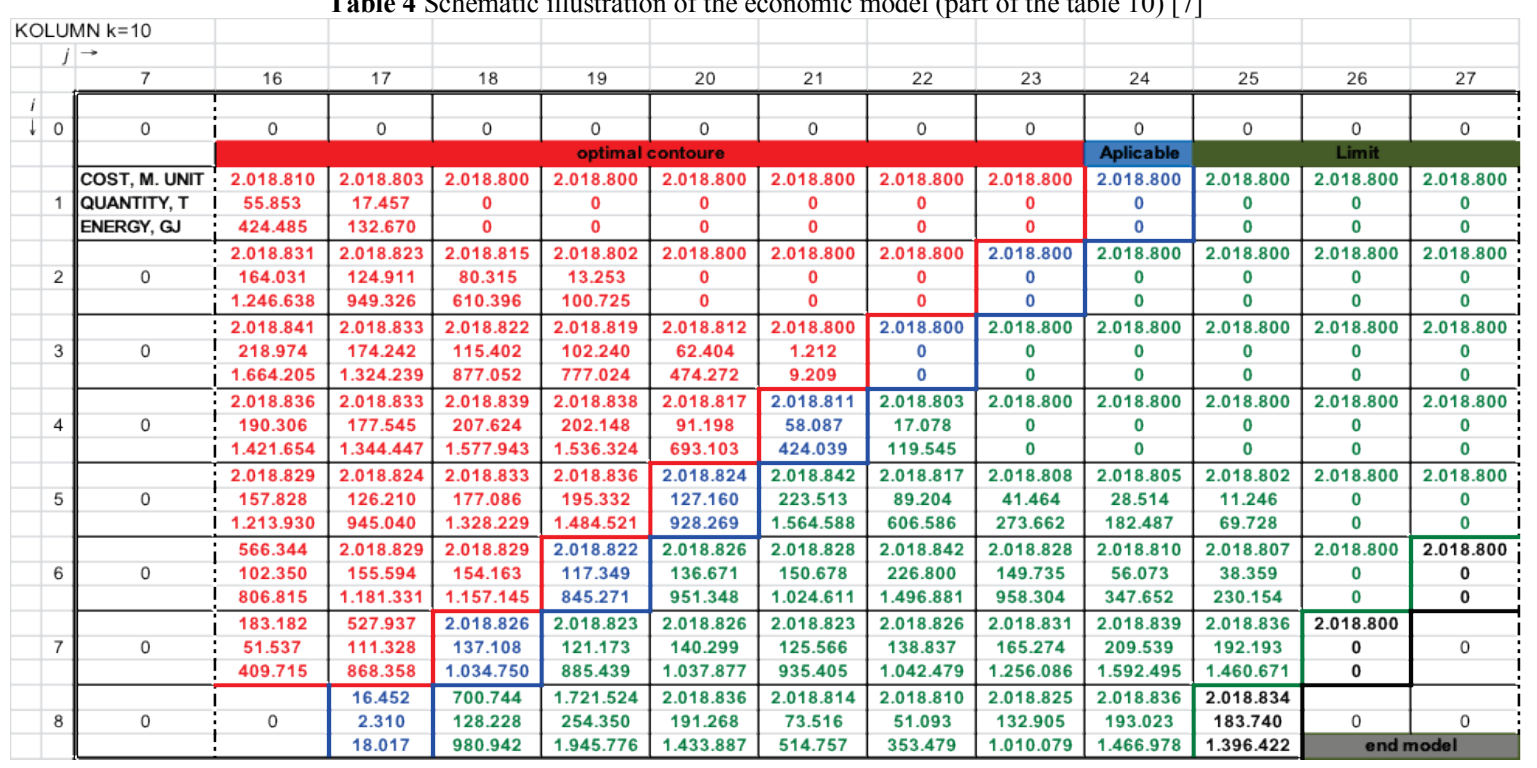

\subsection{Final contours of the open pit}

By economical model of the deposit, final results were obtained, necessary for the procedure of optimization of the open pit contours, i.e. FSM.



Figure 7 Position of the optimal contour of the "Kongora" open pit mine

Optimal contour of the open pit (Po)

By respecting the criteria for optimality, stability and compatibility of the slopes, an optimal contour of the open pit is obtained. The procedure began at the deepest, the richest slope which is situated in the column $11[7,8$, 9]. Summarizing the elements of the first observed (11) and of adjoining contours $(k n+1, k n+2 \ldots \mathrm{k} 30$ and $k n-1$, $k n-2 \ldots k 1$, for $n=11$ ) an optimal contour of the open pit was obtained.

The procedure for defining the utmost profit with the lowest possible production price was elaborated respecting the basic condition that an average price of exploitation of the mineral raw material should be lower than the market price, i.e. $C_{p r}^{O}<C_{t}$. There is no other combination of slopes which would give higher profit and lower production price. The position of the optimal contour of the open pit is displayed in Fig. 7.



Figure 8 Mutual position of the optimal, applied and limit contour on the coal deposit "Kongora"

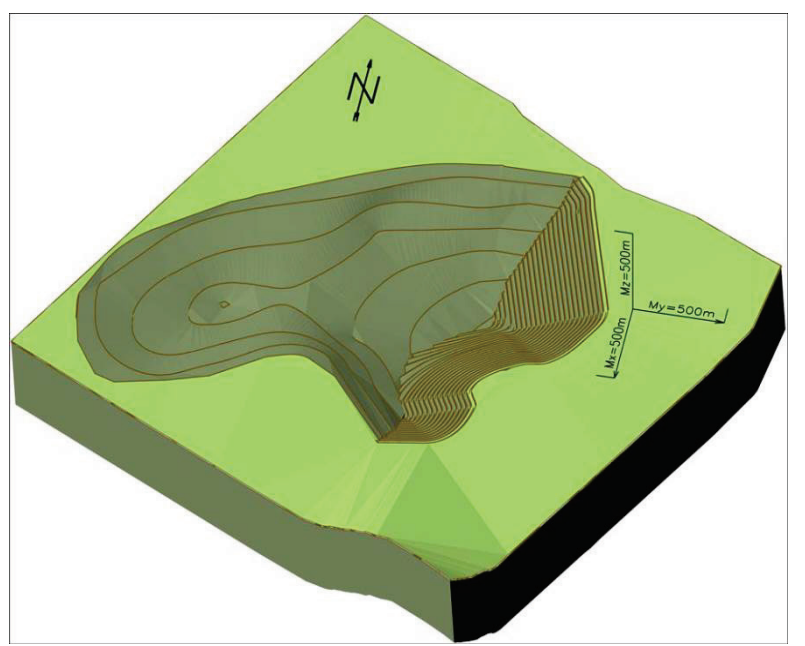

Figure 9 Spatial representation of the optimal contour for the "Kongora" open pit mine, [7] 
Fig. 8 shows the location of all three characteristic contours at the coal deposit "Kongora".

On the basis of the optimal contour, 3D model of the pit was developed and the final geometry of the
"Kongora" open pit was defined (Fig. 9). Tab. 5 presents the summary results of the optimization.

Table 5 Summary of results of the optimization of open pit mine "Kongora" [7]

\begin{tabular}{|c|c|c|c|c|c|c|c|c|}
\hline \multirow[t]{3}{*}{ CONTOURE } & \multirow{3}{*}{$\begin{array}{c}\text { OVER } \\
\text { BURDEN } \\
\mathrm{mil}^{3} \mathrm{~m}^{3} \\
\end{array}$} & \multirow[t]{2}{*}{ COAL } & SPECIFIC & TOTAL & TOTAL & MARKET & PRODUCTION & \multirow{2}{*}{$\begin{array}{c}\text { PROFIT OR } \\
\text { LOSS }\end{array}$} \\
\hline & & & ENERGY & ENERGY & COST & PRICE & PRICE & \\
\hline & & mil.t & $\mathrm{kJ} / \mathrm{kg}$ & PJ & mil. M. UNIT & pico M. UNIT/J & pico M. UNIT/J & mil. M. UNIT \\
\hline FIRST & 0 & 0 & 0 & 0 & 0 & 0 & 0 & 0 \\
\hline OPTIMAL & 287 & 117 & 7448 & 873 & 1877 & 3100 & 2150 & 830 \\
\hline APLICABLE & 327 & 127 & 7377 & 936 & 2112 & 3100 & 2255 & 791 \\
\hline LIMIT & 607 & 163 & 7212 & 1176 & 3639 & 3100 & 3096 & 5 \\
\hline END MODELS & 667 & 167 & 7174 & 1195 & 4002 & 3100 & 3350 & -299 \\
\hline
\end{tabular}

\section{Discussion}

The effectiveness of methods of moving slope can be determined only by the application of specialized software. The algorithms in the FSM are the necessary requirement for developing the $3 \mathrm{D}$ geological model. $3 \mathrm{D}$ geological model is the base for building the block model of the deposit and economic model. Data from the 3D geological model are also a basis for running the process of optimizing the contour of an open pit mine.

The optimization of the sliding slope method for designing the contour of the open pit mine, generates a series of over 100 contours. Among those contours, the following are indicated: optimal, constructive, limiting, starting and finishing contours. All other, unnamed, contours can be placed between these main contours. For the same operating conditions (natural and economic), only one optimal and limiting contour can exist. Every other contour can be used as applied contour depending upon the requirements.

When the pre-set conditions (such as the amount of mineral resources, the depth of exploitation and the life of the mine) for a specific deposit of mineral resources (in this case the coal "Kongora"), are set, then the resulting contour of a mine can be one of the possible calculated contours. The resulting contour may or may not be optimal, according to the criteria largest financial profit gain.



Figure 10 The relationship between the amount of overburden, coal and specific energy in the contours

For any calculation, boundary conditions in the geological model must exist in order to estimate out the optimization of the contour. Otherwise, no optimization of the boundary conditions could last indefinitely in time and space. It is necessary to determine the boundaries of the model, regardless of the economic outcome. According to the data from Table 5, the amount of mineral resources (coal) and overburden increases, regardless of the analysed contours. Therefore, specific energy is variable and reaches the maximum value at the optimum contour (Fig. 10).

The amount of energy that can be produced by thermal power plant, obtained by the contours of the mine "Kongora", increases cumulatively and reaches the maximum at the end of the geological model. This is understandable, because with every new slope, the lower or higher increase in energy will be achieved. Operating costs are also increased to the maximum value at the end of the model. However, the gain is optimal on one contour of the model (Fig. 11).



Figure 11 The relationship between the amount of total energy, total cost and profit or loss in the contours

Also, this contour is significant because it is marginal or critical contour in which the gain decreases to a minimum value or is equal to zero. This is a defined area in which it must be possible to have a contour for the purpose of achieving profit. Otherwise, distancing from the boundary contour towards the end of the model will result with the financial loss (Fig. 11 and 12).

The market price is assumed to be constant, but, in reality it is variable and is determined in complex 4D process optimization that includes time factor as the fourth dimension and estimation of movement of other 
prices in the market. In contrast to the market, production cost is predominantly dependent on the geological model and technological conditions of the exploitation at the pit mine.

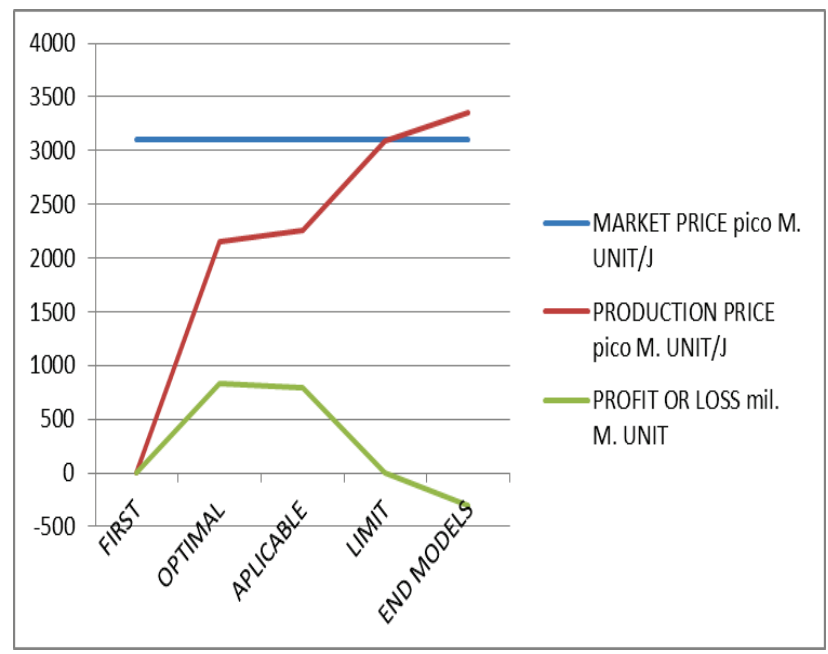

Figure 12 The relationship between the amount of market price, production price and profit or loss in the contours

At any given time the differential profit or loss can be determined and calculated by the difference of production and market price. Profit is achieved when the production cost is lower than the market one and higher when there is a loss in business. That is the critical point of intersection of the market and the production costs of no profit or loss. Then the boundary contour behind that exploitation is not realistic because the profit curve is negative, i.e. deficit occurs.

\section{Conclusions}

Developing the 3D geological model belongs to the modern designing methods that depend on the quantity and quality of input data and data interpretation. The aim of conducted research was to estimate the optimal contour of an open pit mine at coal deposit "Kongora".

The principles of contemporary 3D open pit optimization, primarily applicable for bedded types of deposits and coal seams, are also discussed. Considering the basic criteria for computerized open pit design (the optimality, profitability, and geotechnical slope stability), a new method, named the Floating Slope Method, is introduced and successfully tested at coal open pit mine. Developed algorithm and formulas consider various options of data entry, directions of block excavation, market prices, costs of exploitation, and, as the output produce cost estimation for obtained pit limits and graphical presentation of all steps in optimization process. An example of optimization process illustrates the output values, obtained through the process. The developed calculation model, based on standard set of input data, and different calculation directions, produces accurate final pit limits on coal seams, in open pit cross section and plan view.

Finally, it can be determined that in the coal deposit "Kongora" are considered all the possible contours of the mine, including the characteristic ones: optimal, dedicated and limiting. In the analysis of block model, the potential valuation of one or more mineral resources in the economic model, is determined. It certainly depends on the geological model of the deposits. In coal deposit "Kongora" overburden consists of sand, clay and marl, which can be interesting and can be evaluated integrally. That will significantly change the production costs and thus affect the position of optimal pit mine contour.

\section{References}

[1] Alford, G. G.; Whittle, J. Application of Lerchs-Grossman Pit Optimisation to the Design of Open Pit Mines. // Open Pit Mining Conference / Calgary, 1986, pp. 201-207.

[2] Asad, M. W. A.; Dimitrakopoulos, R. Implementing a parametric maximum flow algorithm for optimal open pit mine design under uncertain supply and demand. // Journal of the Operational Research Society. 64 (2013), pp 185197. DOI: $10.1057 /$ jors.2012.26

[3] Berlanga, J. M.; Cardona, R.; Ibarra, M. A. Recursive formulae for the Floating Cone Algorithm. // Mine Planning and Equipment Selection-International symposium, Balkema / Rotterdam, 1988, pp. 15-25.

[4] Boland, N.; Dumitrescu, I.; Froyland, G.; Gleixner, A.M. LP-based disaggregation approaches to solving the open pit mining production scheduling problem with block processing selectivity. // Computers \& Operations Research. 36(2009), pp. 1064-1089. DOI: 10.1016/j.cor.2007.12.006

[5] Caccetta, L.; Hill, S. P. An Application of Branch and Cut to Open Pit Mine Scheduling. // Journal of Global Optimization. 27, 2-3(2003), pp. 349-365.

[6] Dowd, P.; Onur, A. Optimizing open pit design and sequencing. // Proceedings of 23th International APCOM / Tucston, 1992, pp. 411-422.

[7] Galić, I.; Krasić, D.; Knežiček, T. Defining the optimal point of opening and developing a surface pit mine. // Acta Montanistica Slovaca. 19, 1(2014), pp. 47-59.

[8] Galić, I.; Janković, B.; Mrakovčić, I. Another way for open pit mine design optimization-floating slopes method. // Faculty of mining, geology and petroleum of Zagreb, Mining, Geology and Petroleum Proceedings. 21, (2009), pp. 103-111.

[9] Galić, I. Mining Design using specialized software. Master's thesis, Faculty of Mining, geology and Petroleum Engineering, Zagreb, 2002.

[10] Group of authors. Integrated Lignite Mining and Power Project. Reinbraun Engineering and Wasser GMBH, Germany, 1998.

[11] Isaković, H.; Marinčić, J. Geological structure and level of exploration of lignite Kongora near Tomislavgrad. // Mining and Geology Bulletin Mostar. 12, (2008), pp. 7988.

[12] Koenigsberg, E. The Optimum Contours of an Open Pit Mine: an Application of Dynamic Programming.// Proceedings of 17th International APCOM / New York, 1982, pp. 274-287.

[13] Kostović, G.; Fazlibegović, J. Study on possibility of profitable surface exploitation of lignite deposit "Kongora" in the Duvanjsko field for the requirements of the TE Duvno. Institute for mining investigations Tuzla, 1978.

[14] Knezicek, T. Computer and software methods of designing an Open Pit mine. // Proceedings of Mining-geological Faculty Tuzla. 17, (1995), pp. 28-36.

[15] Knezicek, T. Logic of software for designing an open pit mine on coal deposits. // Proceedings of Mininggeological Faculty Tuzla. 22, (2000), pp. 63-66.

[16] Lerchs, H.; Grossmann, I. F. Optimum Design of Open Pit Mine. // Trans. C. I. M. 68, (1965), pp. 17-27. 
[17] Milojević, R.; Ahac, A. et al. Study on classification, categorization and calculation of coal deposits Kongora. Geoinžinjering, Sarajevo, 1978.

[18] Underwood, R.; Tolwinski, B. A mathematical programming viewpoint for solving the ultimate pit problem. // European Journal of Operat. Research. Elsevier Science B.V. 107, 1(1996), pp. 96-107. DOI: 10.1016/S0377-2217(97)00141-0

[19] Wilke, F. L. et al. Ultimate Pit and Production Scheduling Optimisation. // Proceedings of 18th International APCOM / London, 1984, pp. 29-38.

[20] Whittle, J. Beyond Optimisation in Open Pit Design. // First Canadian Conference on Computer Application in the Mineral Industry. / Quebec, 1988, pp. 331-337.

[21] Wright, A. The Use of Dynamic Programming for Open Pit Mine Design, Some practical implications. // Mining Science and Technology, Elsevier Science Publishers. 4(1987), pp. 97-104. DOI: 10.1016/S0167-9031(87)90214-3

\section{Authors addresses:}

Ivo Galić, Assistant Professor PhD

Department of Mining Engineering and Geotechnics,

Faculty of Mining, Geology and Petroleum Engineering

Pierottijeva 6, 10000 Zagreb, Croatia

tel. (1) 5535872

E-mail: ivo.galic@rgn.hr

\section{Dragan Krasić, Assistant Professor PhD}

Ministry of Economy,

Vukovarska 78, HR-10000 Zagreb, Croatia

tel. (1) 6106972

E-mail: dragan.krasic@mingo.hr 